PhD in Pedagogical Sciences, Associate Professor, BORYS MAKSYMCHUK Mykhaylo Kotsubynskyi Vinnytsya State Pedagogical University, Ukraine Address: 32 Ostrozkogo St., Vinnytsya, 21000, Ukraine

E-mail: maksimchook@gmail.com

\title{
FORMING FUTURE SPECIALISTS' VALEOLOGICAL COMPETENCY: THEORETICAL ANALYSIS OF DOMESTIC AND FOREIGN SCHOLARS' VIEWS
}

\begin{abstract}
The article deals with the analysis of theoretical and methodical principles of forming students' valeological competency in the process of physical education in higher pedagogical education institutions in domestic and foreign scientific literature. It has been defined that one of the most prominent factors in future teachers' training for valeological education is higher pedagogical education. The content and character of its influence determine the way how future teachers are trained to organize valeological education at schools, teach the Basics of Health to the 1-4 graders, adhere to the most important principles of the educational process that ensure a gradual and effective solving of valeological tasks. It has been concluded that the competency-based approach ensures social realization of specialists as it teaches how to solve professional needs and problems that emerge in cognitive, technological and mental activities, in the spheres of ethical, social, legal, professional, personal relations, provides for such educational content that does not contain only a knowledgeoriented component, but also provides integrative experience in solving life problems, carrying out key functions, social roles, realizing competences.

Key words: future teacher, physical education, pedagogical model, valeology, results of the experiment, competency, modeling.

\section{INTRODUCTION}

The mentioned problem is topical for all the countries that makes it extremely global. The main policies and guidelines are discussed and adopted at the international conferences to promote global health. In 1986 Ottawa (Canada) hosted the First International Conference on Health Promotion, whereupon the Ottawa Charter for Health Promotion was adopted (World Health Organization, 1986). It defined health promotion as the process that allows people to increase control over their health and thereafter improve it, so it considers health as a resource for everyday life rather than a goal. The Second International Conference on Health Promotion was held in 1988 in Adelaide (Australia). There were adopted the Adelaide Recommendations on Healthy Public Policy. In 1991 the Third International Conference on Health Promotion was held in Sundsvall (Sweden) and there was adopted the Sundsvall Statement on Supportive Environments for Health. The Fourth International Conference on Health Promotion was convened in Jakarta (Indonesia) in 1997. There was adopted the Jakarta Declaration on Leading Health Promotion into the 21st Century, as well as several applications for active lifestyles, healthy aging, healthy cities, health promoting schools, etc. The Fifth International Conference on Health Promotion was held in Mexico City (Mexico) in 2000 and was devoted to overcoming inequalities in health promotion. The Sixth International Conference on Health Promotion was held in Bangkok (Thailand)
\end{abstract}


in 2005. There was adopted the Bangkok Charter for Health Promotion, that identified those strategic obligations needed to influence the determinants of health in a globalized world through a health promotion approach. The Seventh Conference on Health Promotion was held in Nairobi (Kenya) in 2009. There was decided to call for international actions to address the gap between countries in health and development and for this purpose key strategies were defined (Андрющенко, 2015).

Since the 1970 s personality-oriented approaches, based on the main principles of behavioural science, have been used in planning and carrying out health programs aimed at spreading the principles of a healthy lifestyle (Brown, 1992; Kok, Haes, 1991; Noack, 1987). Complementing each other behavioural theories are focused on interpersonal factors, such as knowledge, attitudes, perceptions, motivation, self-esteem, course of life, past experiences, skills. These include "The Stages of Change Theory" (Prochaska, DiClemente, 1984); "Health Belief Model" (Becker, 1974); "The Consumer Information Processing Theory" (Bettman, 1979). The researchers claim that human behaviour, in addition to individual characteristics, influences interpersonal, institutional, population and political factors (Бобрицька, 2006).

\section{THE AIM OF THE STUDY}

The aim of the paper consists in the analysis of theoretical and methodical principles of forming students' valeological competency in the process of physical education in higher pedagogical education institutions in domestic and foreign scientific literature.

\section{THEORETICAL FRAMEWORK AND RESEARCH METHODS}

Based on the analysis and generalization of relevant researches we have singled out the approaches that contribute to the successful valeological development of students, namely:

- the systemic approach: human is the unity of physical and spiritual. It is impossible to keep one's body healthy and improve the emotional-volitional sphere without taking into account students' spiritual and moral qualities;

- the personality-oriented approach: students master valeological culture through the cooperation with their teachers; it is necessary not to encourage students to promote health, but lead them to it;

- the culture-based approach: human and their health are the values that form the basis of human culture and its important components.

Such methods as synthesis, theoretical analysis, generalization, systematization have been used in the paper.

\section{RESULTS}

In terms of higher education, the most needed qualities for future professional activity are successfully formed if the content of the educational process is at most approximated to the conditions of future specialists' professional activity. Thus, the educational process in higher education institutions complies with the modeling law that requires all the educational events to be filled with the professional content and be implemented in those situations adjusted to reality so that graduates can get acquianted with problems that may emerge during their professional activity. According to the modeling law, the proportion of classes and activities that model future activity is constantly growing due to the introduction of modern innovative learning technologies.

Over the past few decades demands on health have significantly increased. It should be mentioned that the meaning of the term has changed, too. At various times and cultures the definition of health considerably differed. Their authors used many criteria to reveal the essence of health. These are well-being, optimal functioning of the body, the 
balance between human and the environment, the full-blooded human existence and the form of human potential actualization that provides the maximum opportunities for selfcreation (Kok, Haes, 1991) and the process of acmeological development of all the biocultural and social components of human and the continuum (variability and duration) of life states (Максимчук, 2016).

In the classification of definitions of health the authors single out several options: firstly, as the result of certain activities; secondly, as the ability to achieve the set goals or to perform certain functions; thirdly, as the process where health appears as a dynamic phenomenon that is constantly changing; fourthly, as something experienced by an individual; fifthly, as an attribute of the individual (e.g. physical abilities) or the characteristic of the personality (e.g. their emotions) (Максимчук, 2016).

In our oinion, the presented definition is not scientific enough as it describes the ideal state of the individual, which practically does not exist and cannot be measured. The confirmation of our opinion can be found in the works of E. Ekholm who believes that the definition of health set out in the WHO Charter is beyond understanding of scientific statistics (Echolm, 1977) and M. Fomin, who emphasized that the definition proposed by WHO does not meet scientific purposes, as it cannot be measured quantitatively (Андрющенко, 2015). Instead, people are always striving for certain ideals, but one should make an effort to achieve the desired results. As it was stated in the Ottawa Charter for Health Promotion, in order to reach a state of complete physical, mental and social wellbeing, a person or group of people should be able to define and realize their aspirations, satisfy needs, change the environment and cope with it (World Health Organization, 1986). One can achieve well-being through the conscious and purposeful process of creating one's own life, improving one's health and providing it with a responsible attitude to the individual and public health. To some extent, every individual is personally responsible for the health of all humanity, when all humanity is to some extent responsible for the health of every individul (Андрющенко, 2015). In the context of the above, worth noting are C. Riff's patterns of psychological well-being that are appropriate to use when creating methods of forming preschoolers' health-saving competency (when developing approaches to forming children's health-saving skills). According to the author, they are: a positive attitude towards themselves and their past (self-perception); the availability of goals and activities that give meaning to their life (life goals); the ability to meet the requirements of everyday life (competency); the sense (feeling) of continuous development and self-realization (personal growth); relationships with others that are filled with care and confidence (positive attitude to others); the ability to live up to their own beliefs (autonomy) (Андрющенко, 2015).

Nowadays, instead of unilateral, predominantly somatic consideration of health content is used the integrated approach. The concept of health includes all the components of the human body. It is a complex open (for external influences) biocultural and social system that is able to function and exist only in the external environment.

The phenomenon of living systems is ensured by typical specialized structures. The activities of these structures are realized through constant circulation of flows of plastic substances, energy and information within the system as well as between it and the environment. It is these flows that determine the presence of the phenomenon of life being the basis for self-renewal, self-control and self-reproduction of living systems. This is the biological essence of health.

Speaking of human as the highest form of realization of the phenomenon of life, it is important to remember their ability to perceive and run through themselves the picture of 
the world, to feel their place among their own kind and to express themselves through social activity. These abilities characterize mental (emotional and intellectual) and spiritual aspects of health as the highest expressions of human integrity. Higher levels of personality organization, namely, mind and spirituality, can act as either a stimulant or a brake of the biological substrate (Bettman, 1979).

Health is not only a medical and biological category, but social as well. Nothing social can be realized without the biological substrate. Carrying out one's biological and social functions can be interpreted as a manifestation of health. The higher an individual's ability to realize their biological and social functions is, the higher level their health has. The ability to express one's health is greatly influenced by psychological (mental) and spiritual qualities. The compliance of the individual's attitudes and aspirations, on the one hand, and the manifestations of health, on the other hand, create a particular degree of "well-being" - physical, mental and social.

Based on the essential characteristics of health, it can be represented as follows. Health is the dynamic state of human being that is defined by the reserves of the mechanisms of their systems' self-organization (resistance to pathogenic factors and the ability to compensate for the pathological process), is characterized by energetic, plastic and informative (regulatory) provision of self-organization processes and is the basis of manifestation of biological (the ability to survive - the preservation of the individual, the reproduction - procreation) and social functions (Філіпп’єва, 2007).

Scholars point out that the issue of health should be considered in the light of philosophical and scientific and practical world. The priority may be the transition to the valeological paradigm of education and the social and acmeological strategy of valeological education. The valeological paradigm of education is formed on the unity of traditional and innovative approaches to preserving and strengthening students' health. Particularly relevant are such values as knowledge and abilities that allow to choose behavioural patterns within the limits of their own and public safety. An important role in the development of society belongs to valeological literacy of population and teachers, in particular (Максимчук, 2016).

It has been defined that one of the most prominent factors in future teachers' training for valeological education is higher pedagogical education. The content and character of its influence determine the way how future teachers are trained to organize valeological education at schools, teach the Basics of Health to the 1-4 graders, adhere to the most important principles of the educational process that ensure a gradual and effective solving of valeological tasks.

The performed analysis has allowed to conclude that one of the ways to update the content of education and educational technologies and adjust them to modern needs as well as integration in the world educational space is the orientation of curricula toward the competency-based approach and the establishment of effective mechanisms for its implementation.

The competency-based approach ensures social realization of specialists as it teaches how to solve professional needs and problems that emerge in cognitive, technological and mental activities, in the spheres of ethical, social, legal, professional, personal relations, provides for such educational content that does not contain only the knowledge-oriented component, but also provides integrative experience in solving life problems, carrying out key functions, social roles, realizing competences.

The competency-based approach changes the purpose and vector of higher education content from knowledge and skills transmission to the substantive content of 
training (formation) of the personality with developed life and professional competencies. The introduction of the competency-based approach in the educational process involves the development of integrated courses where the subject fields relate to different types of competencies as well as the expansion of an intersubject component in the structure of curricula. The competency-based approach in education is grounded the on multidisciplinary, integrated requirements to the result of the educational process. When looking for main or priority competencies one should refer to the concept of key (basic) competencies that characterizes the universal competencies of a wide range, which form the basis for the forming of competences with a more specific application (Максимчук, 2016).

In the context of the educational reforms in the 1980s in EU countries there emerged the question of competency as a necessary product of education. EU experts define the concept of "competence" as "the ability to apply knowledge and skills", which provides the active use of educational achievements in new situations. Each competency is based on the combination of cognitive complementary attitudes and practical skills, values, emotions and behavioural components, knowledge and skills, that can be mobilized for an active action (Short, 1985).

The International Commission of the Council of Europe considers the concept of "competency" as "general or core skills, basic abilities, fundamental ways of learning, key qualifications, cross-learning abilities or skills, fundamentals or basic knowledge" (OECD, 2016). Competencies include the ability to perceive and respond to individual and social needs. Competency is a set of attitudes, values, knowledge and skills.

M. Mulder defines competency as a person's ability to achieve the defined results (Mulder, Biemans, 2004). According to the British psychologist J. Raven, one of the authors of the competency-based approach in English education, "competency is a specific capability required for the effective implementation of specific actions in a particular subject area covering professional knowledge, substantive skills, ways of thinking and understanding of responsibility for one's actions" (Андрющенко, 2015). Of the same opinion is T. Hyland, who defines competency as the ability to perform specific activities according to the specified standard (Hyland, 2001).

It is generally agreed today that the competency-based approach originated in the USA and one of the first publications that emphasize this issue is D. McClelland's "Testing for Competence Rather Than for "Intelligence" (McClelland, 1973). Thus, the concept of educational competency has come to us from foreign countries where it is widely used and studied. However, it has been found out that in domestic pedagogy the competency-based approach in determining the goals and content of education is not entirely new and borrowed from the West. The orientation toward mastering abilities and generalized tools of activity was crucial in the work of such educators as I. Lerner, G. Shchedrovytskyi, M. Skatkin and their followers. However, for various reasons this orientation was applied and developed abroad. Implementing the competency-based approach, pedagogical science today relies on the foreign experience, adjusting it to Ukrainian traditions and needs.

Within our paper we would like to characterize one of the components of professional competency, namely, an ability. In pedagogical and psychological literature there is still no common understanding of the nature and essence of abilities. In some cases, the ability is defined as the person's capability to perform actions (N. Bilokur, F. Mileryan, K. Platonov), in other cases - as a part of activity and is defined as an action (V. Bezpalko, I. Lerner, N. Talyzina). Some scholars refer the "ability" to the category of activity and define it as a conscious possession of any technique of activity (Yu. Babanskyi, A. Leontyev). 
According to D. Gorbatyi, all three positions relate to the existing levels of the mental phenomena analysis in the framework of the theory of activities. The interpretation of abilities as a way to perform any activity corresponds to the macro-level, the interpretation of abilities as the capability is the meso-level and the characteristic of abilities as a separate action - a micro-level analysis of these phenomena.

The definition of "pedagogical abilities" is the most important for our study. Pedagogical abilities are psychological formations that combine professional and personal knowledge and skills with mental and practical actions ensuring the success of the educational process. The degree of formation and the level of skills development depends on the personality traits, nature and content of professional knowledge, skills and experience that are included in the mental and practical actions during solving the educational problems. Achieving the goals at every stage of the control cycle is ensured by using a set of professional skills.

However, according to some scholars, it is better not to oppose competencies and traditional knowledge and abilities as any competency is based on them, as well as certain knowledge (efficiency, effectiveness) characterizes the student's ability to use the acquired knowledge in practical activities and situations.

In the context of this study rather interesting is the position of E. Short, an American educator, who considers the competency under four different angles:

1) as the combination of abilities, skills, patterns of behaviour and actions within a specific activity;

2) as the combination of knowledge, abilities and skills in professional activity without evaluation criteria;

3 ) as the combination of the same elements, but with the use of standards;

4) as the combination of abilities and personal qualities of the individual (Short, 1985).

Analyzing the system based on the forming of students' pedagogical abilities, it is worth noting that pedagogical abilities involve the ways and methods of activities directed at the deliberate use of psychological, pedagogical and methodological knowledge in practice. These creative deliberate actions of a teacher are aimed at achieving a certain goal. They are carried out only on the basis of profound theoretical and practical knowledge.

\section{CONCLUSIONS}

So, the performed analysis has allowed to conclude that one of the ways to update the content of education and educational technologies and adjust them to modern needs as well as integration in the world educational space is the orientation of curricula toward the competencybased approach and the establishment of effective mechanisms for its implementation.

Rather perspective for further researches we consider the study of forming students' valeological competency in the process of physical education in higher education institutions in Ukraine and abroad.

\section{REFERENCES}

1. Becker, M. H. (1974). The Health Belief Model and Personal Health Behaviour. Health Education Monograph Series, Volume 2, pp. 324-508.

2. Bettman, J. R. (1979). An Information Processing Theory of Consumer Choice. Reading, MA : Addison-Wesley, $402 \mathrm{p}$.

3. Brown, E. R. (1992). Health USA : A National Health Program for the United States. JAMA, Volume 267, No 4, pp. 552-558. 


\section{DE GRUYTER}

OPEN

Порівняльна професійна педагогіка 6(4)/2016 Comparative Professional Pedagogy 6(4)/2016

4. Echolm, E. P. (1977). The Picture of Health. Environmental Sources of Disease. New York: W.W. Norton, 256 p.

5. Glanz, K., Lewis, F. V., Rimer, B. K. (1990). Health Behavior and Health Education: Theory, Research and Practice. San Francisco : Jossey Bass, 592 p.

6. Hyland, T. (2001). Book Review of Competency-Based Education and Training: a World Perspective by A. Arguelles and A. Gonczi. Journal of Vocational Education and Training, Volume 53, No 3, pp. 487-490.

7. Kok, G., Haes, de W. (1991). Research in Health Education and Promotion. Hygie, Volume 10, No 2, pp. 12-15.

8. McClelland, D. C. (1973). Testing for Competence rather than for "Intelligence". American Psychologist, Volume 28, No 1, pp. 1-14.

9. Mulder, M., Biemans, H. (2004). Competence-Based VET in Netherlands: Background and Pitfalls. Journal of Vocational Education and Training, Volume 56, No 4, pp. 523-538.

10. Noack, N. (1987). Concepts of Health and Health Promotion. In : Abelin, T., Brzeziński, Z. J., Carstairs, V. D. L. (Eds.). Measurements in Health Promotion and Protection. Copenhagen : WHO. Regional Office for Europe, pp. 5-28.

11. OECD. (2016). Definition and Selection of Competencies. Theoretical and Conceptual Foundations (DeSeCo). Retrieved 16.11.2016 from : http://www.oecd.org/ edu/skills-beyond-school/definitionandselectionofcompetenciesdeseco.htm.

12. Prochaska, J. O., DiClemente, C. C. (1984). The Transtheoretical Approach : Crossing Traditional Boundaries of Therapy. New York : Dow Jones-Irwin, 193 p.

13. Short, E. (1985). The Concept of Competence: Its Use and Misuse in Education. Journal of Teacher Education, Volume 36, No 2, pp. 2-6.

14. World Health Organization. (2005). The Bangkok Charter for Health Promotion in Globalized World. Retrieved 13.12.2016 from : http:/www.who.int/healthpromotion/ conferences/6gchp/bangkok_charter/en/.

15. World Health Organization. (1986). The Ottawa Charter for Health Promotion. Retrieved 13.12.2016 from : http://www.who.int/healthpromotion/conferences/previous/ottawa/en/.

16. Андрющенко, Т. К. (2015). Теоретико-методичні засади формування здоров'язбережувальної компетентності в дітей дошкільного віку [Theoretical and Methodical Principles of Forming Preschoolers' Health-Saving Competencies]. Doctoral Thesis. Умань, 503 p. (in Ukrainian).

17. Бобрицька, В. I. (2006). Теоретичні і методичні основи формування здорового способу життя у майбутніх учителів у прочесі вивчення природничих наук [Theoretical and Methodical Principles of Forming Future Teachers' Healthy Way of Life while Studying Natural Sciences]. Doctoral Thesis. Київ, 489 р. (in Ukrainian).

18. Гомонюк, О. М. (2016). Значення інформаційно-комунікаційних технологій у формуванні валеологічної компетентності майбутніх педагогів [The Significance of Information and Communication Technologies in Forming Future Teachers' Valeological Competency]. Збірник наукових працьь Національної академії Державної прикордонної служби Украӥни імені Б. Хмельницького. Серія: Педагогічні та психологічні науки [The Collection of Scientific Papers of the Bohdan Khmelnytskyi National Academy of the State Border Guard Service of Ukraine. Series: Pedagogical and Psychological Sciences], No 1 (74), pp. 72-94 (in Ukrainian).

19. Гомонюк, О. М. (2016). Особливості формування валеологічної компетентності як складової професійно-педагогічної культури майбутнього 
педагога [Peculiarities of Forming Valeological Compenecy as a Component of Future Teachers' Culture]. Сучасні інформаційні технології та інноваиійні методики навчання у підготовиі фахівиів: методологія, теорія, досвід, проблеми [Modern Information Technologies and Innovative Teaching Methodology of Specialist Training: Methods, Theory, Experience, Problems], No 46, pp. 149-154 (in Ukrainian).

20. Гуревич, Р. С. (2012). Професійна спрямованість вивчення загальноосвітніх дисциплін у профільній школі [Professional Trends in Mastering General Disciplines in Specialized School]. Сучасні інформачійні технології та інноваиійні методики навчання у підготовиі фахівиів: методологія, теорія, досвід, проблеми [Modern Information Technologies and Innovative Teaching Methodology of Specialist Training: Methods, Theory, Experience, Problems], No 33, pp. 3-7 (in Ukrainian).

21. Костюкевич, В. М. (2010). Факторная структура специальных способностей хоккеистов на траве высокой квалификации [The Factor-Based Structure of Hockey Players' Special High Quality Abilities on the Grass]. Фізична культура, спорт та здоров'я наиії [Physical Culture, Sport and the Nation's Health], No 10, pp. 74-82 (in Ukrainian).

22. Максимчук, Б. А. (2016). Формування валеологічної компетентності майбутніх учителів у прочесі фізичного виховання (теоретико-методичний аспект) [Forming Future Teachers' Valeological Competency in the Course of Physical Education (Theoretical and Methodical Aspect]. Вінниця : ТОВ фірма "Планер", 385 p. (in Ukrainian).

23. Максимчук, І. А. (2012). Провідні компоненти змісту діяльності вчителя фізичної культури у контексті розвитку педагогічної майстерності [The Main Components of Physical Education Teachers' Activity in the Context of Pedagogical Mastery Development]. Сучасні інформачійні технології та інновачійні методики навчання у підготовиі фахівиів: методологія, теорія, досвід, проблеми [Modern Information Technologies and Innovative Teaching Methodology of Specialist Training: Methods, Theory, Experience, Problems], No 33, pp. 393-398 (in Ukrainian).

24. Максимчук, I. А. (2012). Формування педагогічної майстерності майбутнього учителя фізичної культури [Forming Pedagogical Mastery of Future Physical Education Teachers]. Сучасні інформачійні технології та інноваційні методики навчання у підготовиі фахівиів: методологія, теорія, досвід, проблеми [Modern Information Technologies and Innovative Teaching Methodology of Specialist Training: Methods, Theory, Experience, Problems], No 29, pp. 419-423 (in Ukrainian).

25. Філіпп'єва, О. А. (2007). Підготовка майбутніх учителів початкових класів до валеологічного виховання учнів [Training Future Primary Schools Teachers for Valeological Education]. Thesis for PhD. Миколаїв, 254 p. (in Ukrainian). 